IZA DP No. 9496

Improving the Integration of Refugees: An Early Evaluation of a Swedish Reform

Pernilla Andersson Joona

Alma W. Lanninger

Marianne Sundström

November 2015 


\title{
Improving the Integration of Refugees: An Early Evaluation of a Swedish Reform
}

\author{
Pernilla Andersson Joona \\ SOFI, Stockholm University \\ and IZA
}

\author{
Alma W. Lanninger \\ SOFI, Stockholm University
}

Marianne Sundström

SOFI, Stockholm University

\section{Discussion Paper No. 9496 \\ November 2015}

\author{
IZA \\ P.O. Box 7240 \\ 53072 Bonn \\ Germany \\ Phone: +49-228-3894-0 \\ Fax: +49-228-3894-180 \\ E-mail: iza@iza.org
}

Any opinions expressed here are those of the author(s) and not those of IZA. Research published in this series may include views on policy, but the institute itself takes no institutional policy positions. The IZA research network is committed to the IZA Guiding Principles of Research Integrity.

The Institute for the Study of Labor (IZA) in Bonn is a local and virtual international research center and a place of communication between science, politics and business. IZA is an independent nonprofit organization supported by Deutsche Post Foundation. The center is associated with the University of Bonn and offers a stimulating research environment through its international network, workshops and conferences, data service, project support, research visits and doctoral program. IZA engages in (i) original and internationally competitive research in all fields of labor economics, (ii) development of policy concepts, and (iii) dissemination of research results and concepts to the interested public.

IZA Discussion Papers often represent preliminary work and are circulated to encourage discussion. Citation of such a paper should account for its provisional character. A revised version may be available directly from the author. 
IZA Discussion Paper No. 9496

November 2015

\section{ABSTRACT \\ Improving the Integration of Refugees: An Early Evaluation of a Swedish Reform*}

This paper is an early evaluation of the Swedish Establishment Reform which was enacted in 2010 with the goal of facilitating and speeding up the integration of refugees and their family into the labor market and the society. From December 1, 2010 the reform transferred the responsibility for the integration of newly-arrived refugees from the municipalities to the government funded Public Employment Service through which those eligible would get an establishment plan and a coach. The reform was motived by concern over the low employment level and slow integration of refugees. Our approach is to compare the outcomes of the treatment group, which took part in establishment activities and arrived between December 1, 2010 and December 31, 2011, to those of the comparison group, which arrived in the eleven months preceding the Reform and participated in municipal introduction programs, controlling for a rich set of observables, including country of birth and date of residence permit. Outcomes are measured in terms of employment and earnings in 2012 for the treatment group and in 2011 for the comparison group. Our data comes from registers held by Statistics Sweden and the Public Employment Service and covers all immigrants. Although there are good reasons to expect positive effects of the Reform we find no significant difference in employment or earnings between the treatment group and the comparison group.

JEL Classification: $\quad \mathrm{J} 15, \mathrm{~J} 61, \mathrm{~J} 68$

Keywords: integration, refugees, labor market policy, treatment effect, employment, earnings, caseworkers

Corresponding author:

Marianne Sundström

Swedish Institute for Social Research (SOFI)

Stockholm University

SE10691 Stockholm

Sweden

E-mail: masu@sofi.su.se

* We are grateful to Tomas Korpi, Eskil Wadensjö and seminar participants at ESPE 2015 and SOFI for their thoughtful comments and to the Swedish Department of Labor for financial support. 


\section{Introduction}

In recent decades, the number of refugees seeking asylum in Sweden has risen strongly. In fact, among the European countries only Germany has received more asylum seekers. Receiving and integrating are, however, two different things. For quite long it has been clear that Sweden is not doing well when it comes to the establishment of newly arrived immigrants into the labor market and the society. Thus, the difference in employment rates between foreign-born and native-born persons is larger than, for example in Germany, about 12 percentage-points, as compared to 9 percentage-points in 2007 - 2009 according to OECD (2010). Among the foreign-born, refugees have the lowest employment rates. Policymakers have seen it as particularly worrisome that it takes very long for refugees to become employed. For example, compared to natives of the same age and gender, refugees who arrived in Sweden in 1997 - 1999 still had about 25 percentage-points lower rates of employment twelve years after their arrival (Statistics Sweden 2014). Thus, designing and implementing appropriate policies to facilitate the integration of refugees is crucial.

With this aim, the previous Swedish government enacted the so-called Establishment Reform in 2010, which transferred the responsibility for the establishment of newly arrived refugees from the municipalities to the central government, that is, to the Public Employment Service (PES). ${ }^{1}$ According to the new law (SFS 2010:197), from December 1, 2010 all recently arrived refugees and their next of kin should register with their local PES in order to get an Establishment Talk, an Establishment Plan, Establishment Benefits and a coach. The Reform targets new immigrants 20 - 64 years ${ }^{2}$ who have been granted residence permits for refugee reasons or for family reunion with a refugee, and who are not ill, in school full time or work full time.

\footnotetext{
${ }^{1}$ At the same time the government commissioned the Swedish Institute for Social Research to conduct an evaluation of the reform one year after its enactment and a final one two years later. The first report was published in April 2015; see Andersson Joona, Lanninger and Sundström (2015).

${ }^{2}$ The reform also targets refugees 18 - 19 years old that do not have parents in Sweden but they are not included in our study since we measure outcomes in terms of employment, income and regular education. Also, they are very few.
} 
The purpose of this paper is to study the short-term effects of the Reform on employment, earnings and educational activity of refugees who have had residence permits between one and two years. Our data are an excerpt from the register database STATIV of Statistics Sweden covering all individuals who immigrated to Sweden from January 1, 2009 to December 31, 2011. For our study, the data has been supplemented with information from the PES. Our approach is to compare the difference in outcomes between those who arrived from December 1, 2010 until December 31, 2011 (the Treatment group), and participated in the Establishment Program, and those who had arrived just before that, January November 2010 (the Comparison group), and had participated in municipal Integration Programs. We adopt this approach because one can reasonably argue that continuation of the municipal programs is the counterfactual to the reform.

We measure outcomes in 2012 for the Treatment group and in 2011 for the Comparison group and are able to control for a rich set of observables, such as gender, year of birth, education, country of birth and refugee category. Also, since outcomes are measured in two different calendar years, we control both for number of days of national registration and year and quarter of residence permit, that is, when he/she was received in a municipality. Further, as the labor-market conditions may differ across years and regions, we also control for county in which the receiving municipality is located.

In the next section we present the Establishment Reform, its meaning and target group as well as the previous system of introduction of refugees. In Section 3 we review the previous Swedish studies of integration measures as well as the experiences and studies from the other Nordic countries. We discuss our data, method, empirical specification and variables in Section 4. Section 5 reports our findings and Section 6 concludes.

\section{The Establishment Reform}

\subsection{Aim and target group}

The aim of the Reform was to change the program for introduction of certain newly-arrived immigrants in order to facilitate and speed-up their establishment into the labor market and the society. The background was that the integration process was generally seen as too slow and too long (Swedish Government Bill 
2009/10:60). There was, further, a large variation across municipalities in the reception of refugees as well as the organization of introduction measures and in how well these worked (Board of Integration, 2007). The Reform is likely to have been influenced by the experiences of the other Nordic countries in which the central government exercised more control over the integration programs as well as by the findings in previous research that intensive counseling and coaching from case workers increased the probability of employment among newly arrived immigrants. We discuss these background factors in further detail in Section 3.

The Reform targets newly arrived immigrants aged $20-64$ years who have been granted residence permits as refugees or other asylum seekers. As mentioned, the Reform also covers refugees $18-19$ years old without parents in Sweden, but they are not included in this study (see note 2). The Reform further targets those who have been granted residence permits for family reunion with a refugee provided that they have arrived less than two years after that refugee. The Reform does, however, not target those who work full time, study in secondary school or are in such poor health that they cannot work at least 25 percent of full time. We have no information on the health of the refugees, nor do we know - for the family reunion cases - how long the first arriving refugee has been in the country, but discuss how we solve this in Section 4.2 .

The new law implied that from December 1, 2010 all newly arrived in the target group should register with the PES, which is in charge of the Establishment Program. The PES shall offer Establishment Talks during which the experiences and merits of the individual are clarified in order to draw up an Establishment Plan. Each registered person is entitled to get such a plan within two months after he/she received his/her residence permit. The Plan should cover at most 24 months and include Swedish for immigrants, orientation about Swedish society and measures preparing the participant for work. The municipalities are responsible for the classes in Swedish and those about Swedish society, while the other activities in the Plan can be performed by the PES or other agents. The PES is also responsible for helping the refugees find housing if needed. An important part of the Establishment Program was to give the participants more intensive coaching than the previous system did. Thus, the PES would offer the 
participant coaches operating on its behalf in order to assist the participant in fulfilling their Plan by providing them with advice, contacts and coaching. Since it was believed that the varying needs of the participants could best be met if the PES was complemented by private agents, they got the right to choose an Establishment Coach among several private agents. Those who have got an Establishment Plan and participate in Establishment activities are entitled to Establishment Benefits and in certain cases also housing benefits. The benefits are individual and equal across the country. If the participants work for pay while following a plan, they may in most cases keep their benefits and may continue to do so during the whole time with a plan, for at most 24 months, or until they have worked full time for six months or begun tertiary education.

\subsection{The previous system of introduction}

According to the previous legislation, those who had been granted residence permits for refugee related reasons or as next of kin of such a person (if they arrived within two years) should have the right to a place in an Introduction Program in the municipality where they lived. The municipality was reimbursed for the program participation for at most 24 months by the Migration Board. For participants of working ages consultations with the local employment services should take place and for all above 16 years of age the program should include Swedish for immigrants, practical work experience and orientation about the Swedish society. The program quality varied, however, across the country. The participants received Introduction Benefits or social assistance. The municipalities were free to decide what type of benefits they paid and their level, and if benefits, or part of them, could be kept if the participants had other income. Thus, benefit levels varied across the country (Eriksson 2010, Section 5.2.1).

\subsection{Implementation of the Reform}

Follow-ups by the PES indicate that in many municipalities the newly arrived have not received their Establishment Plan within two months after their residence permits. This holds especially for municipalities which had limited experience of receiving refugees because the Migration Board only recently organized housing there (The Public Employment Service, 2013). Many of the newly arrived also had problems supporting themselves, since participants obtain Establishment Benefits once a month but only after taking 
part in the activities. A third problem in the implementation is that many of the newly arrived are unable to participate in the activities because of poor physical and mental health. This was true for about one-third of the newly arrived according to The Swedish National Audit Office (2014a). A fourth problem is that there has been a shortage of housing for the newly arrived in many municipalities; about 60 per cent of the municipalities reported that such shortage is a rather large or very large obstacle for the settlement of refugees (The County Administrative Boards, 2013).

Thus, because of the problems that the newly arrived have had with health, economic support and housing, and the limited experience of the caseworkers of dealing with such problems, the Reform has not worked as intended. The Swedish National Audit Office (2014a) reports that the contacts between the caseworkers and the participants have been dominated by discussions of the participant's economic situation and reports of non-attendance. Further, The Swedish Agency for Public Management (2012) maintains that the activities in the Establishment Plans have not been well suited to the needs and qualifications of the participants. The coach system has also been heavily criticized for not being sufficiently focused on labor market activities -- the coaches have mainly offered social support-- and not being professionally run (The Swedish National Audit Office, 2014b). ${ }^{3}$

When evaluating the Reform, it is important to have these limitations in mind. However, even if the Reform did not work as intended, it may still have had more a favorable impact than the previous system which had other shortcomings. How these effects balance out is an empirical question which we attempt to answer in our analysis.

\section{Previous studies of introduction measures}

\subsection{Swedish studies}

Previous research on the effects of introduction measures on the integration of newly arrived persons in the Swedish labor market has not found clear positive results. Svantesson and Aranki (2006) is based on a survey made in 2004 by the Integration Board to caseworkers in the 52 largest municipalities about types of

\footnotetext{
${ }^{3}$ The coach system was abolished in February 2015.
} 
introduction measures included in the Introduction Programs. They found that those newly arrived who had had activities related to the labor market, such as work practice, have a higher probability of employment in both the short and the long run than those who participated in other activities. A limitation of the study is that the authors have not taken selectivity into account, that is, that those more qualified easier find positions in the labor market. By contrast, Johansson and Åslund $(2006,2011)$ evaluate SIN (Special Introduction), a pilot workplace introduction program for recent immigrants which started in 20 municipalities in 2003. At first, the intention was that the PES case workers should take part in the work place introduction but in practice they mainly worked with search and matching assistance. The experiment led to an increased inflow to work practice, which, in turn, raised the probability of regular employment. There was, however, no direct effect of participating in the SIN-experiment on regular employment.

Further, in 2006 a trial introduction program for newly arrived immigrants was introduced in three counties: Kronoberg, Skåne and Stockholm. ${ }^{4}$ Among the participating municipalities, nine adopted the program as a randomized experiment, in which the PES case workers assigned the newly arrived to the program or the normal activities of the PES by a lottery. Those who participated in the experiment received intensive counseling and coaching from case workers with substantially reduced caseloads compared to other caseworkers. Evaluating the experiment, Andersson Joona and Nekby (2012) found that the program participants had about five percentage-points higher probability of regular employment in the end of the trial period. This result applied, however, only to men, for women there was no difference between the treatment and the control group.

Closely related to our study, Liljeberg and Sibbmark (2011) evaluated an experiment with Establishment Talks that took place in 2009 - 2010 on the initiative of the Swedish Government (Swedish Government, 2008). The trial Establishment Talks targeted refugees and their next of kin and were organized as a collaboration between the Migration Board and the PES. The evaluation is based on interviews with caseworkers at the PES and staff at the Migration Board and register data from PES and Statistics Sweden. The data are used to descriptively compare the outcomes of the participants in the

\footnotetext{
${ }^{4}$ The trial program was phased out on June 30, 2008.
} 
experiment to a comparison group of similar refugees who were registered at the PES but did not take part in the Establishment Talks. ${ }^{5}$ Initially the experiment was carried out in four cities, Göteborg, Skellefteå, Karlskrona and Kristianstad, but from March 2010 it was extended to about twenty more places all over the country. Outcomes are examined in the end of 2009 for the four initial cities and in the end of 2010 for all who took part in talks or were in the comparison group in the extended experiment until April 2010, all in all about 2000 persons who had Establishment Talks. The results show that refugees who had Establishment Talks, on average, met the PES earlier and were sooner enrolled in a labor market program than those who did not have such talks. Very few had left the PES for employment. Since the experiment in practice worked as a pilot project for the Establishment Reform, it most likely influences our results which we comment on in the concluding section.

Thus, the findings of previous studies indicate that measures which are closely linked to the labor market and to a high degree resemble regular employment increase the probability of finding work for new immigrants. It has also been found that intensive coaching has a positive impact on job chances, at least for men. These findings are likely to have inspired the changes in the integration policy that was carried out by the enactment of Establishment Reform.

\subsection{Nordic experiences and studies}

Although Sweden has had a much larger inflow of immigrants than Denmark and Norway during the whole post-war period, the three countries have had similar migration experiences up to the start of this millennium. They all had labor migration in the 1950s and the 1960s and refugee immigration in the 1980s and, especially, in the 1990s (for a review and comparison with Finland and Iceland, see Korpi, Bäckman and Minas, 2015). After this point, Denmark deviated by restricting the right to asylum and family reunion; restrictions that were partly motivated by the difficulties of immigrants to find employment. When it comes to integration policies, there are also many similarities. Thus, while the Danish policy has implied reduced benefits and more restricted criteria for receiving benefits, from 2002 Denmark also had a start-help

\footnotetext{
${ }^{5}$ The main reason why these refugees did not participate in the Establishment Talks was probably that they lived in places where there were no such talks according to the authors.
} 
program which included language classes and work oriented training. Thereby, the program resembled the Swedish Introduction Program introduced in 1994, the Finnish in 1999 and the Norwegian introduced in 2003. The programs differed by being mandatory for refugees in Denmark, Norway and Finland, but voluntary in Sweden. Another important difference was that the central government in Denmark, but to some extent also those in Norway and Finland, exercised more control over the municipal integration programs than that in Sweden did. Denmark had, for example, quite detailed directions regarding the contents of the programs, while in Sweden this was largely not the case. A third difference lay in the use of sanctions, for example, when program participants did not turn up for classes or did not apply for a job referral. Such sanctions were mandatory in the programs of Denmark, Finland and Norway, whereas in Sweden the municipalities were free to decide whether to introduce them or not.

Korpi et al (2015) compare and analyze trends in employment among natives, immigrants from western countries and immigrants from non-western countries aged 30 - 59 years in Denmark, Finland, Norway and Sweden over the period 1993 - 2006, that is, before and after the reforms. Their results suggest that the growth in employment among non-western immigrants has been somewhat higher in Denmark than in the other countries and that this is mainly due to the changes in the integration policy rather than the more restrictive migration policy (p. 98). These findings are consistent with Danish, Finnish and Norwegian evaluations which indicate that measures, such as the availability of subsidized employment and language classes, have had positive employment effects, and that the reduced benefit levels in Denmark also have had positive effects, but more limited, see for example Clausen et al (2009), Huynh et al (2010). Korpi et al (2015) conjecture that the integration programs have had similar positive effects in all Nordic countries, but the larger increase in employment in Denmark is likely related to the central funding and the higher quality of the programs and to some extent to the reduced benefit levels in the start-help program.

Most likely, the experiences of the other Nordic countries, especially Denmark, with more control from the central government have influenced the previous Swedish government in transferring the responsibility for the integration of new immigrants from the municipalities to the central government and 
making the programs more uniform through the Establishment Reform. Based on the results from the other Nordic countries we would, thus, expect the Reform to have a positive impact on the employment of new migrants. 


\section{Data, method and variables}

\subsection{Data}

We use an excerpt from the database STATIV of Statistics Sweden covering all immigrants to Sweden in 2009 - 2011 (Statistics Sweden 2013). For our study, Statistics Sweden has supplemented the data with information from the PES on the individuals' participation in the Establishment Program. We have excluded all individuals who received residence permits for other than refugee reasons or family reunion with a refugee and those younger than 20 years or older than 65 years in the year they immigrated. All data have been de-identified.

\subsection{Method}

We analyze the difference in outcomes of the Treatment group and the Comparison group. As mentioned, we adopt this approach because one can reasonably argue that continuation of the municipal programs is the counterfactual to the Reform. The model to be estimated can be specified in the following way:

$Y_{i t}=\alpha_{0}+\gamma R E F O R M_{i}+\delta T I M E_{i}+b^{\prime} X+\varepsilon_{i}$

where $Y_{i t}$ is the outcome for individual $i$ : Employment and earnings, $t$ is equal to 2011 if the individual belongs to the Comparison group and equal to 2012 if the individual belongs to the Treatment group. REFORM $=0$ for the Comparison group $=1$ for the Treatment group

$\gamma$ is the parameter of interest.

TIME is measured by a set of dummy variables which are equal to 1 for the year and quarter of the year the individual received his/her residence permit and equal to 0 otherwise.

$B^{\prime} X$ is a vector of control variables, including gender, year of birth, country of birth, level of education, refugee category, days of national registration and county of residence, $\varepsilon$ is the random error. 
Further, this simple model (1) assumes that the control variables are proportional to the Reform, that is, that they have the same impact for the Treatment and Comparison group. Since this does not necessary hold, we also run interactions between the Reform and each of the control variables.

We use two criteria for classifying the refugees and their next of kin into the Treatment and Comparison groups. The first criterion is the date of residence permit, that is, when the individual obtained permission to reside in a certain municipality, where those in the Treatment group received their residence permits between December 1, 2010 and December 31, 2011 and those in the Comparison group in the immediately preceding period, January 1 to November 30,2010 . The second criterion is whether the individuals were enrolled in the Establishment Program and had an Establishment Plan - the Treatment group - or in the Introduction Program, that is, had received introduction benefits or social welfare combined with introduction benefits - the Comparison group. By using this criterion we circumvent the problem that we do not know the health of the individuals, nor how long the first arrived refugees in the family reunion cases have been in the country.

As mentioned, we measure outcomes in terms of employment, annual earnings and enrolment in education. The fact that outcomes are measured in 2012 for the Treatment group and in 2011 for the Comparison group gives rise to three problems: First, the individuals differ in how long they have lived in Sweden when outcomes are measured. Second, the labor-market conditions may vary between the two years. In fact, the unemployment rate was marginally lower in 2011 than in 2012 with an annual average of 7.8 percent as compared to 8.0 percent in 2012 for both sexes (Statistics Sweden). Third, the experience and expertise of the staff handling integration measures may differ between the municipalities and the PES. We deal with the first problem by controlling for the quarter of year the individual received the residence permit as well as the number of days of national registration in the end of 2010 and 2011, respectively. Thereby, the second problem is partly solved and, in addition, we include controls for county in which the municipality of residence is located. The third problem we have no way of dealing with, unfortunately, as we cannot observe the skills of those handling integration issues. Clearly, we are comparing a new program with apparent starting problems with a well-established system which had some shortcomings. 


\subsection{Variables}

\subsubsection{Control variables}

Besides gender and year of birth our control variables are country of birth, educational attainment, refugee category, days of national registration and county of residence. Country of birth is divided into Afghanistan, Eritrea, Europe, Iraq, Iran, Somalia, other African country, other Asian country, other Middle-East country and other regions. ${ }^{6}$ Educational attainment is grouped into the levels Primary Education less than nine years, Lower Secondary, Upper Secondary, Post-Secondary Education and Unknown education. Refugee category is grouped into the following categories: Quota Refugee, Housing through the Migration Board, Own Housing and Family Reunion with a refugee who had arrived less than two years earlier. ${ }^{7}$ Days of national registration is a continuous variable measured in 100-days in the end of 2011 for the Treatment group and in the end of $\mathbf{2 0 1 0}$ for the Comparison group. County of residence has been classified into eight categories based on in which county the municipality of residence is located, Stockholm; Västra Götaland; Skåne, Halland and Blekinge; Uppsala, Gävleborg and Västmanland; Södermanland and Östergötland; Örebro, Värmland and Dalecarlia; Jönköping, Kronoberg, Kalmar and Gotland, and Västernorrland, Jämtland, Västerbotten and Norrbotten.

Descriptive statistics on the control variables for the two groups is reported in Table 1 . We see that the groups are fairly similar in gender and age composition, refugee category and county of residence, but differ noticeable in education and country of birth. As expected, both groups have low levels of education and while the fraction with less than nine years of schooling is higher in the Treatment group, the fraction with unknown or missing education is higher in the Comparison group. Most likely, this is because the Treatment group has been able to report their educational attainment to the PES which, in turn, has included the information in the data base. Further, we see that the fraction born in Somalia is almost twice as large in the Comparison group, while the fractions born in Afghanistan, Eritrea and Iraq are larger in the

\footnotetext{
${ }^{6}$ This classification distinguishes the major countries of origin and is as detailed as available in the data.

${ }^{7}$ This classification may seem peculiar but it is the one in the data. Own housing and Migration Board Housing refer to the housing during the asylum process; those with own housing mainly lived as lodgers with relatives and friends and the others in housing provided by the Migration Board. Quota refugees have residence permits before they arrive in Sweden.
} 
Treatment group. Finally, the Treatment group has had more days of national registration and more months of residence permits in the end of 2011 than the Comparison group had in the end of 2010, which is as expected since we follow the former group longer. The fraction that has had their residence permits for four quarters of the year is larger in the Comparison group, however.

For women the frequencies are very similar to those for both sexes for all except two variables. First, the fraction of family reunion cases is higher among women, and, second, the fraction with less than nine years schooling and that with unknown education are higher among women. These differences hold for both the Treatment and the Comparison group.

\subsubsection{Outcome variables}

As mentioned, outcomes are measured in terms of employment, annual earnings and enrolment in regular education and observed in 2012 for the Treatment group and in 2011 for the Comparison group. In particular, the variable employed is equal to 1 if the individual was employed in November 2012 or 2011, respectively, as recorded by Statistics Sweden, or if the individual was employed sometime during the year according to an income report from an employer to the tax authorities, and 0 otherwise. We have no information on how much the individual worked or whether it was regular or subsidized employment. ${ }^{8}$ Annual earnings is the total gross wage income received during the year in 2012 prices and measured in SEK100s. We define student as equal to 1 if the individual is recorded as in education in the fall semester ${ }^{9}$ of 2012 and 2011, respectively, and has not been participating in Swedish for immigrants during the year, and 0 otherwise.

We present means and frequencies for our outcome variables by time with residence permit in 2011 and 2010, respectively, for the Treatment and Comparison groups in Table 2. As expected, the fraction employed increases by time with residence permit for both groups. We also see that among those who had residence permits less than three-quarters of a year the fraction employed is lower in the Comparison group, but among those who had permits for four quarters it as about 26 per cent for both groups. The

\footnotetext{
${ }^{8}$ Follow-ups from the PES show that subsidized work dominates among those who have been employed, about 77 per cent among men and 72 per cent among women (The Public Employment Service, 2013).

${ }^{9}$ Information is only available for the fall semester.
} 
fraction that has a wage income is, of course, very similar to the fraction employed. The median wage income is rather similar and very low in both groups. Finally, we find that the fraction enrolled in regular education is similar and very low in both groups and, therefore, we cannot perform a statistical analysis of this outcome. For women the fraction employed is considerably lower than among men and so is the median wage income. The fraction of students is also lower among women but the difference as compared to both sexes is not as large as for employment and wage income.

Thus, the displayed means and frequencies suggest a great similarity in outcomes of the groups. It is interesting to see whether this similarity prevails after our multivariate analysis, which we now turn to, has taken account of differences in background characteristics and time in Sweden.

\section{Findings}

We now turn to the results starting with the effect of the Establishment Reform on the probability of employment. The estimates are presented in Table 3 which for reasons of clarity displays coefficients for Reform and gender only (see Appendix Table A for a table with all coefficients and standard errors). The other control variables are included stepwise and we indicate the sign of their association with the dependent variable and the level of significance and comment on them below. We see that the Reform has a positive impact on the probability of employment in model (1), in which we only control for gender and year of birth, but when controls for country of birth are added in model (2) the coefficient is no longer statistically significant and when we account for level of education in model (3) it turns negative and significant. It remains negative and significant when we include controls for refugee category in model (4), days of national registration in model (5), quarter of year with residence permit in model (6) and county of residence in model (7).

Thus, it would appear as if the Reform has a negative effect on the probability of employment. This would, however, be to jump to conclusions since model (7) is not a complete model. We need to account for possible effects of interactions between the Reform and any of the independent variables, that is, that the impact of the control variables may differ between the Treatment and Comparison group. In order to investigate this, we tested adding interactions between the Reform and each of the control variables, in 
turn, to model (7). We found that only the interaction between the Reform and refugee category was statistically significant and improved the fit of the model. The resulting estimates are presented in model (8) and show a positive but not significant effect of the Reform on the probability of being employed any time during the year.

We now briefly discuss the associations between the control variables and the probability of employment based on the results in model (7). Clearly, the results indicate that women have a lower probability of employment than men, about 15 percentage points lower. Younger persons have a higher probability of employment than older persons. When it comes to country of birth, refugees from Iraq have lower probability of employment than those from other countries. Further, as expected, having at least nine years of education is positively correlated with employment whereas unknown education is negatively correlated. As to refugee category, we find that refugees who live in own housing more often are employed than the other categories. This may be a selection effect since they may be more motivated and have better ties with the Swedish society. The positive interaction effect indicates that this is even more so for the Treatment group than the Comparison group, which may reflect that those with own housing had an advantage after the Reform as they did not need help with housing and more quickly could get started with their Establishment Plan. Unsurprisingly, number of days of national registration increases the probability of employment and so does time since receiving residence permit. When it comes to county, those living in Stockholm County and those living in Norrland have higher employment than those living elsewhere.

While we found no difference between the Treatment and Comparison group in the probability of being employed any time during the year, there may still be differences between them in how much they worked. One way of examining this - as information on annual hours worked is not available - is to analyze differences in annual wage income, which we now turn to. As for employment, we present only the coefficients for Reform and gender while for the other control variables we show the sign and level of statistical significance (Table 4). (All coefficients and standard errors can be found in Appendix Table B). We see that the estimated effect of the Reform is small in absolute value and not statistically significant in any model. As before, we tested for effects of interactions between the Reform and the independent variables 
and found that only the interaction with refugee category was statistically significant and improved the fit of the model. We abstain from presenting the resulting estimates here, since the coefficient for Reform is positive but not statistically significant and the other estimates do not differ much from those in model (7), but they can be found in Andersson Joona et al 2015, Table 5 D. Finally, the large negative coefficient for women is striking, implying that in both groups of newly arrived refugees, women have about 24 percent lower annual wage income after differences in age, education and other factors have been accounted for.

\section{Conclusions}

This paper is an early evaluation of the Establishment Reform introduced in 2010 by the former Swedish government. The purpose is to study the effects of the Reform on the establishment of newly arrived refugees in the labor market as measured by employment, wage income and enrollment in regular education one to two years after arriving in Sweden. We do this by comparing the outcomes for the Treatment group with those for the Comparison group. The Treatment group consists of refugees and their next of kin 20 - 64 years who arrived in the period December 1, 2010 to December 31, 2011 and participated in the Establishment Program while the Comparison group consists of similar individuals who arrived in the preceding period, January 1 to November 30, 2010 and participated in the municipality Introduction Programs. We analyze the difference in outcomes of the Treatment and Control group measuring outcomes in 2012 for the Treatment group and in 2011 for the Comparison group controlling for a rich set of background characteristics, including country of birth, education, county of residence, time of arrival and days lived in Sweden. The analysis is based on an excerpt from the register database STATIV of Statistics Sweden covering all immigrants to Sweden in 2009 to 2011. For our study the data has been supplemented by information from the Public Employment Service.

Although there are good reasons to expect some positive effects of the Reform, our findings indicate that there was no significant difference between the two groups in the probability of being employed anytime during 2012 and 2011, respectively, after all control variables and interaction effects had been taken into account. The fraction employed was low and similar in the Treatment and Comparison group, about 27 per cent among those who had had residence permits for four quarters of the preceding year. 
When it comes to annual wage income the results were similar; no significant difference between the two groups. For women in both groups we found considerable lower probability of any employment, 15 percentage-points lower, after all control variables had been included. Also, women in both groups had about 24 per cent lower annual wage income, everything else equal. Finally, we found that the fraction which had been enrolled in regular education was equally low in both groups, about 6 per cent among those who had had residence permits for four quarters of the preceding year, which is too few to permit a multivariate analysis of differences.

So how can we explain why do we not find an effect of the Reform? We see three possible explanations that are not mutually exclusive for this result: First, we are comparing a new program with evident start-up problems to a program which had shortcomings but was well-established. Second, many of the refugees in the Comparison group had taken part in the experiment with Establishment Talks described in Section 3.1, which should make their outcomes more similar to those of the Treatment group. Third, the programs and the training that the Treatment group receives may be of higher quality and last for longer time so that they simply have not had time to find work yet.

In our final report, in which we will have one more year of data on both the Treatment and Comparison group when both groups have completed their 24 months of program participation, we will be able to assess the effects of the Reform with greater certainty and see if any of the above explanations for lack of short term effects are valid. 


\section{References}

Andersson Joona, Pernilla, Lanninger, Alma W. and Marianne Sundström (2015) Etableringsreformens första år - en första utvärdering. SULCIS Report 2015:3, Stockholm University www.su.se/sulcis/publikationer/rapportserie/2015

Andersson Joona, Pernilla and Lena Nekby (2012) Intensive coaching of new immigrants: An evaluation based on random program assignment, Scandinavian Journal of Economics, 114(2):576-600.

Åslund, Olof and Per Johansson (2006) Arbetsplatsintroduktion för vissa invandrare - teori, praktik och effekter, Rapport 2006:6, IFAU, Uppsala

Åslund, Olof and Per Johansson (2011) Virtues of SIN: Can increased public efforts help Disadvantaged immigrants? Evaluation Review, 35(4):399-427

Board of Integration (2007), Ett förlorat år. En studie och analys av insatser och resultat under introduktionens första 12 månader, Report 2007:05, Integrationsverket.

Clausen, Jens, Heinesen, Eskil, Hummelgaard, Hans, Husted, Leif and Michael Rosholm (2009) The effect of integration policies on the time until regular employment of newly arrived immigrants: Evidence from Denmark, Labour Economics 16:409-417.

County Administrative Boards (2013) Mottagande och etablering av nyanlända 2012 - Resultatet av en enkätundersökning riktad till Sveriges kommuner, Länsstyrelserna.

Eriksson, Stefan (2010) Utrikesfödda på den svenska arbetsmarknaden. Bilaga 4 till LU2011. Stockholm: Fritzes.

Huynh, Duy T., Schultz-Nielsen, Marie Louise and Torben Tranæs (2010) The employment effects upon arrival of reducing welfare to refugees, in M. L. Schultz-Nielsen, Essays in migration and fertility, Ph. d. dissertation, Aarhus School of Business, Aarhus University.

Korpi, Tomas, Bäckman, Olof and Renate Minas (2015) Att möta globaliseringen. Rapport 2015:534, Tema Nord, Nordiska ministerrådet.

Liljeberg, Linus and Kristina Sibbmark (2011) Uppföljning av etableringssamtal. Rapport 2011:28. IFAU, Uppsala.

OECD (2010) Trends in international migration. Paris

Public Employment Service (2013) Etablering av vissa nyanlända-analys av genomförandet. Avser januari - april 2012, Arbetsförmedlingen.

SFS (Swedish Statute Book) 2010:197, Lag om etableringsinsatser för vissa nyanlända invandrare, www.notisum.se 2014-01-17

Statistics Sweden (2013) Dokumentation av databasen STATIV, se www.scb.se/stativ/.

Statistics Sweden (2014), Integration - etablering på arbetsmarknaden (Integration - establishment on the labor market). Integration. Rapport 7. 
Svantesson, Elisabeth and Ted Aranki (2006) Do Introduction Programs Affect the probability of Immigrants getting Work?, Örebro University, Working Paper No. 3.

Swedish Agency for Public Management (2012) Etablering av nyanlända: En uppföljning av myndigheternas genomförande av etableringsreformen, Statskontoret 2012:22.

Swedish Government (2008) Uppdrag att bedriva försöksverksamhet med etableringssamtal. Arbetsmarknadsdepartementet 2008-12-18.

Swedish Government Bill 2009/10:60, Nyanlända invandrares arbetsmarknadsetablering-egenansvar med professionellt stöd. http://ec.europa.eu/ewsi/UDRW/images/items/docl 19549 607965119.pdf

Swedish National Audit Office (2014a) Att tillvarata och utveckla nyanländas kompetens - Rätt insats i rätt tid? RIR 2014:11, Riksrevisionen.

Swedish National Audit Office (2014b) Etableringslotsar - fungerar länken mellan individen och arbetsmarknaden? RIR 2014:14, Riksrevisionen. 
Table 1. Means and frequencies for the control variables for the treatment and comparison groups. Per cent.

\begin{tabular}{|c|c|c|c|c|}
\hline \multicolumn{3}{|c|}{ Treatment group } & \multicolumn{2}{|c|}{ Comparison group } \\
\hline & All & Women & All & Women \\
\hline Women & 47.9 & & 48.6 & \\
\hline \multicolumn{5}{|l|}{ Year of Birth: } \\
\hline $1944-1953$ & 3.6 & 3.7 & 3.8 & 3.8 \\
\hline $1954-1963$ & 9.9 & 11.0 & 8.5 & 8.6 \\
\hline $1964-1973$ & 18.5 & 19.3 & 18.6 & 17.5 \\
\hline $1974-1983$ & 32.5 & 31.3 & 35.0 & 33.5 \\
\hline $1984-1992$ & 35.6 & 34.7 & 34.1 & 36.6 \\
\hline \multicolumn{5}{|l|}{ Refugee Category: } \\
\hline Quota Refugee & 15.5 & 15.3 & 11.6 & 11.8 \\
\hline Migration Board Housing & 31.0 & 30.8 & 33.5 & 31.7 \\
\hline Own Housing & 43.6 & 40.0 & 45.0 & 42.9 \\
\hline Family Reunion & 9.9 & 139 & 10.0 & 13.7 \\
\hline \multicolumn{5}{|l|}{ Education } \\
\hline Primary $<9$ years & 40.3 & 46.8 & 23.8 & 29.2 \\
\hline Lower Secondary & 9.6 & 8.6 & 6.2 & 5.0 \\
\hline Upper Secondary & 19.2 & 16.5 & 13.5 & 10.1 \\
\hline Post Secondary & 19.5 & 18.1 & 17.9 & 13.0 \\
\hline Unknown & 11.3 & 10.0 & 38.6 & 42.8 \\
\hline \multicolumn{5}{|l|}{ Country/Region of birth } \\
\hline Afghanistan & 8.7 & 8.9 & 4.1 & 5.1 \\
\hline Eritrea & 13.8 & 14.7 & 7.6 & 8.6 \\
\hline Europe & 2.5 & 2.4 & 2.7 & 2.9 \\
\hline Iraq & 19.0 & 20.5 & 14.1 & 14.6 \\
\hline Iran & 7.0 & 6.2 & 4.4 & 3.6 \\
\hline Somalia & 28.7 & 28.7 & 53.6 & 52.0 \\
\hline Other African country & 8.9 & 9.0 & 5.3 & 5.4 \\
\hline Other Asian country & 4.8 & 4.3 & 3.8 & 3.7 \\
\hline Other Middle-Eastern country & 6.0 & 4.7 & 3.8 & 3.5 \\
\hline Other Regions & 0.6 & 0.6 & 0.6 & 0.7 \\
\hline \multicolumn{5}{|l|}{ County } \\
\hline Stockholm & 17.3 & 17.7 & 15.7 & 16.4 \\
\hline Västra Götaland & 15.7 & 15.2 & 18.0 & 16.7 \\
\hline Skåne, Halland, Blekinge & 14.0 & 13.9 & 9.5 & 9.6 \\
\hline Uppsala, Gävleborg, Västmanland & 10.5 & 11.2 & 13.9 & 14.2 \\
\hline Södermanland, Östergötland & 11.6 & 12.2 & 9.6 & 9.9 \\
\hline Örebro, Värmland, Dalarna & 9.7 & 9.4 & 12.0 & 12.2 \\
\hline Jönköping, Kronoberg, Kalmar et al & 8.4 & 7.2 & 11.2 & 10.2 \\
\hline Norrbotten, Västernorrland et al & 13.0 & 13.2 & 10.0 & 10.8 \\
\hline National registration, days & 248.2 & 252.0 & 238.7 & 238.1 \\
\hline Residence permit, months & 6.9 & 6.7 & 5.6 & 5.6 \\
\hline Residence permits 1 q of $2011 / 2010$ & 18.2 & & 16.8 & \\
\hline 2 quarters of $2011 / 2010$ & 22.5 & & 21.5 & \\
\hline 3 quarters of $2011 / 2010$ & 31.0 & & 29.3 & \\
\hline 4 quarters of $2011 / 2010$ & 28.3 & & 32.7 & \\
\hline Observations & 5.300 & 2.538 & 6.597 & 3,209 \\
\hline
\end{tabular}


Table 2 Means and frequencies for the outcome variables by time with residence permit. Per cent and EUR.

Treatment group 2012

Comparison group 2011

\begin{tabular}{|c|c|c|c|c|}
\hline & All & Women & All & Women \\
\hline 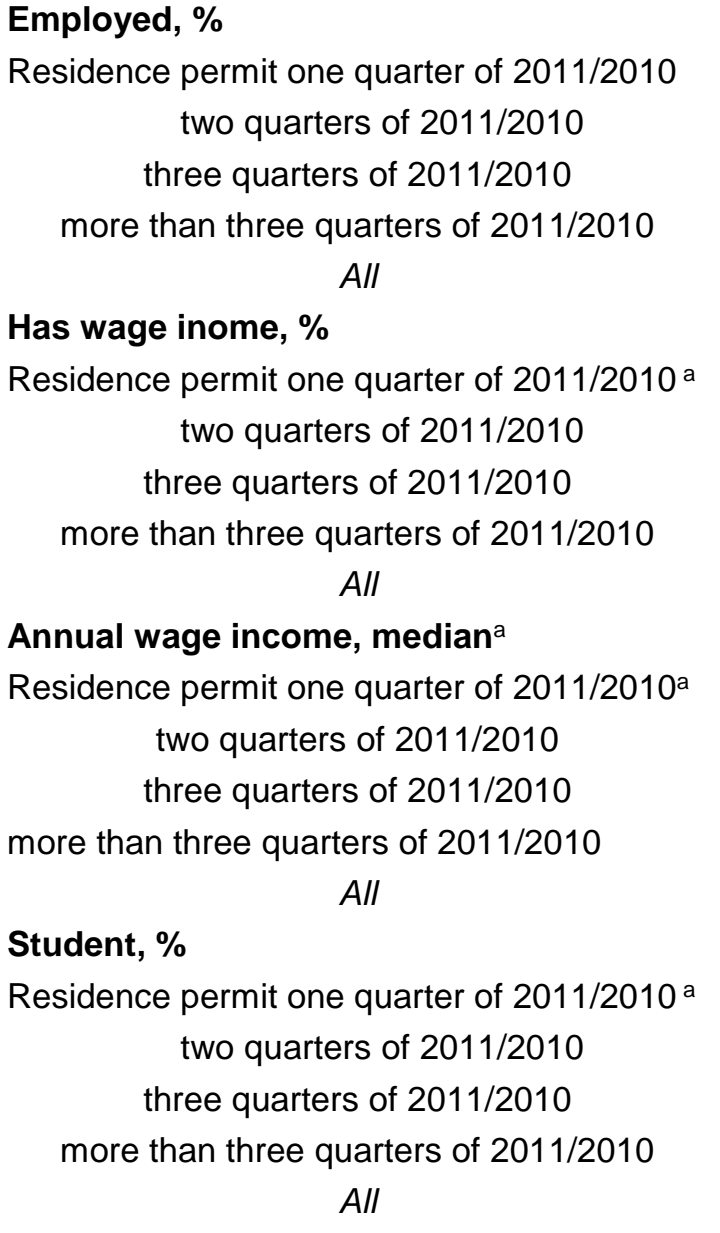 & $\begin{array}{l}20.2 \\
21.5 \\
24.4 \\
26.9 \\
23.6 \\
\\
19.9 \\
21.4 \\
24.1 \\
26.6 \\
23.5 \\
\\
43.7 \\
57.6 \\
54.5 \\
62.9 \\
55.7 \\
\\
2.3 \\
3.4 \\
3.9 \\
6.0 \\
4.1\end{array}$ & $\begin{array}{l}13.2 \\
13.2 \\
13.2 \\
16.8 \\
14.3 \\
\\
13.2 \\
13.2 \\
13.2 \\
16.7 \\
14.3 \\
\\
27.6 \\
43.0 \\
45.2 \\
47.4 \\
43.8 \\
\\
2.5 \\
2.0 \\
3.9 \\
4.9 \\
3.6\end{array}$ & $\begin{array}{l}40.8 \\
51.1 \\
44.7 \\
66.8 \\
51.5 \\
\\
1.0 \\
2.2 \\
3.3 \\
5.8 \\
3.5\end{array}$ & $\begin{array}{l}38.9 \\
45.4 \\
33.8 \\
62.9 \\
44.5 \\
\\
0.9 \\
1.9 \\
2.4 \\
4.1 \\
2.6\end{array}$ \\
\hline
\end{tabular}

a Reported in EUR10s in 2012 prices for those with positive wages according to the exchange rate in October 2015. 
Table 3. Estimates of the effect of the Establishment Reform on the probability of employment in 2012 as compared to the effect for the Comparison group in 2011. Both sexes.

\begin{tabular}{|c|c|c|c|c|c|c|c|c|}
\hline Variabler & (1) & (2) & (3) & (4) & (5) & (6) & (7) & (8) \\
\hline Reform & $\begin{array}{c}0.017^{* *} \\
{[0.008]}\end{array}$ & $\begin{array}{l}-0.007 \\
{[0.008]}\end{array}$ & $\begin{array}{c}-0.029^{* * *} \\
{[0.008]}\end{array}$ & $\begin{array}{c}-0.032^{* * *} \\
{[0.008]}\end{array}$ & $\begin{array}{c}-0.034^{* * *} \\
{[0.008]}\end{array}$ & $\begin{array}{c}-0.030^{* * *} \\
{[0.008]}\end{array}$ & $\begin{array}{c}-0.027^{* * *} \\
{[0.008]}\end{array}$ & $\begin{array}{c}0,018 \\
{[0.011]}\end{array}$ \\
\hline Female & $-0.167^{* * *}$ & $-0.167^{\star \star \star}$ & $-0.145^{\star * *}$ & $-0.139^{\star * *}$ & $-0.142^{* * *}$ & $-0.143^{\star * *}$ & $-0.146^{\star * *}$ & $-0,146^{* * *}$ \\
\hline Year of birth & Pos. ${ }^{* *}$ & Pos. ${ }^{* *}$ & Pos. ${ }^{* * *}$ & Pos. ${ }^{* *}$ & Pos. ${ }^{* * *}$ & Pos. ${ }^{* * *}$ & Pos. ${ }^{* *}$ & Pos. ${ }^{* * *}$ \\
\hline Afghanistan & & Pos. ${ }^{* *}$ & Pos. ${ }^{* * *}$ & Pos. ${ }^{* *}$ & Pos. ${ }^{* *}$ & Pos. ${ }^{* * *}$ & Pos. ${ }^{* *}$ & Pos. ${ }^{* * *}$ \\
\hline Eritrea & & Pos. ${ }^{* *}$ & Pos. ${ }^{* *}$ & Pos.** & Pos. ${ }^{* *}$ & Pos. ${ }^{* *}$ & Pos. ${ }^{* \star *}$ & Pos. ${ }^{* *}$ \\
\hline Europe & & Pos. ${ }^{* *}$ & Pos. ${ }^{* * *}$ & Pos. ${ }^{* *}$ & Pos. ${ }^{* *}$ & Pos. ${ }^{* * *}$ & Pos. ${ }^{* *}$ & Pos. ${ }^{* * *}$ \\
\hline Iraq & & & & & & & & 0 \\
\hline Iran & & Pos. ${ }^{* *}$ & Pos. ${ }^{* * *}$ & Pos. ${ }^{* *}$ & Pos. ${ }^{* *}$ & Pos. ${ }^{* * *}$ & Pos. ${ }^{* *}$ & Pos. ${ }^{* *}$ \\
\hline Somalia & & Neg. ${ }^{* *}$ & Pos. & Pos. & Pos. & Pos. & Pos. & Pos. ${ }^{* *}$ \\
\hline Other African country & & Pos. ${ }^{* *}$ & Pos. ${ }^{* * *}$ & Pos. ${ }^{* *}$ & Pos. ${ }^{* *}$ & Pos. ${ }^{* * *}$ & Pos. ${ }^{* *}$ & Pos. ${ }^{* *}$ \\
\hline Other Asian country & & Pos.** & Pos. ${ }^{* \star *}$ & Pos.** & Pos.** & Pos. ${ }^{* \star *}$ & Pos. ${ }^{* \star}$ & Pos. ${ }^{* * *}$ \\
\hline Other Middle Eastern & & Pos. ${ }^{* *}$ & Pos. ${ }^{* *}$ & Pos. ${ }^{* *}$ & Pos. ${ }^{* *}$ & Pos. ${ }^{* *}$ & Pos. ${ }^{* *}$ & Pos.*** \\
\hline Other Regions & & Pos.** & Pos. ${ }^{* *}$ & Pos.** & Pos.** & Pos. ${ }^{* \star *}$ & Pos. ${ }^{* \star}$ & Pos. ${ }^{* * *}$ \\
\hline Primary Educ. $<9$ years & & & & & & & & 0 \\
\hline Lower Secondary Educ. & & & Pos. ${ }^{* *}$ & Pos. ${ }^{* *}$ & Pos. ${ }^{* *}$ & Pos. ${ }^{* *}$ & Pos.* & Pos. ${ }^{*}$ \\
\hline Upper Secondary Educ. & & & Pos. ${ }^{* * *}$ & Pos. ${ }^{* *}$ & Pos. ${ }^{* *}$ & Pos. ${ }^{* * *}$ & Pos. ${ }^{* *}$ & Pos. ${ }^{* *}$ \\
\hline Post Secondary Educ. & & & Pos. ${ }^{* *}$ & Pos. ${ }^{* * *}$ & Pos. ${ }^{* *}$ & Pos.*** & Pos. ${ }^{* \star *}$ & Pos. ${ }^{* *}$ \\
\hline Unknown Education & & & Neg. ${ }^{* \star *}$ & Neg. ${ }^{* *}$ & Neg. ${ }^{* * *}$ & Neg. ${ }^{* * *}$ & Neg. ${ }^{* * *}$ & Neg. ${ }^{* * *}$ \\
\hline Own Housing & & & & 0 & 0 & 0 & 0 & 0 \\
\hline Quota Refugee & & & & Neg. & Neg. & Neg.* & Neg. ${ }^{* *}$ & Neg.** \\
\hline Migration Board Hous. & & & & Neg. ${ }^{* * *}$ & $\mathrm{Neg}^{* * *}$. & Neg. ${ }^{* * *}$ & Neg. ${ }^{* \star *}$ & Neg. \\
\hline Family Reunion & & & & Neg. ${ }^{* * *}$ & Neg. ${ }^{* * *}$ & Neg. ${ }^{* * *}$ & Neg. ${ }^{* *}$ & Neg.** \\
\hline National Registr. Days & & & & & Pos. ${ }^{* *}$ & Pos. $^{* *}$ & Pos. ${ }^{* *}$ & Pos. ${ }^{* *}$ \\
\hline Residence Permit $1 \mathrm{q}$. & & & & & & & & 0 \\
\hline Residence Permit 2 q. & & & & & & Pos. & Pos. & Pos. \\
\hline Residence Permit 3 q. & & & & & & Pos. ${ }^{* *}$ & Pos.*** & Pos. ${ }^{* *}$ \\
\hline Residence Permit $4 \mathrm{q}$. & & & & & & Pos. ${ }^{* *}$ & Pos. ${ }^{* * *}$ & Pos. ${ }^{* * *}$ \\
\hline Stockholm County & & & & & & & & 0 \\
\hline Västra Götaland & & & & & & & Neg. ${ }^{* * *}$ & Neg. ${ }^{* *}$ \\
\hline Skåne, Halland et al & & & & & & & Neg. ${ }^{* * *}$ & Neg. ${ }^{* * *}$ \\
\hline Uppsala, Gävleborg et al & & & & & & & Neg.** & Neg.*** \\
\hline Södermanland et al & & & & & & & Neg. ${ }^{* \star}$ & Neg.** \\
\hline Örebro, Värmland et al & & & & & & & Neg. ${ }^{* * *}$ & Neg. ${ }^{* * *}$ \\
\hline Jönköping, Kalmar et al & & & & & & & Neg. ${ }^{* *}$ & Neg.*** \\
\hline Västernorrland et al & & & & & & & Pos. & Pos. \\
\hline ReformQuota Refugee & & & & & & & & Neg. ${ }^{* *}$ \\
\hline ReformMigBoard Hous. & & & & & & & & Neg. ${ }^{* *}$ \\
\hline ReformFamily Reunion & & & & & & & & Neg.** \\
\hline Observations & 11,897 & 11,897 & 11,897 & 11,897 & 11,897 & 11,897 & 11,897 & 11,897 \\
\hline Adjusted $\mathrm{R}^{2}$ & 0.055 & 0.074 & 0.09 & 0.0952 & 0.1021 & 0.103 & 0.1244 & 0.1283 \\
\hline
\end{tabular}

Reform is equal to 1 if the individual belongs to the Treatment group and equal to 0 if he/she belongs to the Comparison group. Values for the reference groups are marked as $0 .{ }^{* * *} p<0.01,{ }^{* *} p<0.05,{ }^{*} p<0.1$ 
Table 4. Estimates of the effect of the Establishment Reform on log annual earnings in 2012 as compared to the effect for the Comparison group in 2011. Both sexes.

\begin{tabular}{|c|c|c|c|c|c|c|c|}
\hline Variables & (1) & (2) & (3) & (4) & (5) & (6) & (7) \\
\hline $\begin{array}{l}\text { Year of birth } \\
\text { Afghanistan } \\
\text { Eritrea } \\
\text { Europe } \\
\text { Iraq } \\
\text { Iran } \\
\text { Somalia } \\
\text { Other African Country } \\
\text { Other Asian Country } \\
\text { Other Middle Eastern } \\
\text { Other Regions } \\
\text { Primary Educ. < } 9 \text { years } \\
\text { Lower Secondary Educ. } \\
\text { Upper Secondary Educ. } \\
\text { Post Secondary Educ. } \\
\text { Unknown Education } \\
\text { Own Housing } \\
\text { Quota Refugee } \\
\text { Migration Board Hous. } \\
\text { Family Reunion } \\
\text { National Registr., Days } \\
\text { Residence Permit } 1 \text { q. } \\
\text { Residence Permit } 2 \text { q. } \\
\text { Residence Permit } 3 \text { q. } \\
\text { Residence Permit } 4 \text { q. } \\
\text { Stockholm County } \\
\text { Västra Götaland } \\
\text { Skåne, Halland, Blekinge } \\
\text { Uppsala, Gävleborg et al } \\
\text { Södermanland et al } \\
\text { Örebro, Värmland et al } \\
\text { Jönköping, Kalmar et al } \\
\text { Västernorrland et al } \\
\text { Sula }\end{array}$ & $\begin{array}{c}0.090 \\
{[0.007]} \\
-0.239^{\star \star \star} \\
{[0.061]} \\
\text { Neg. }{ }^{\star \star *}\end{array}$ & $\begin{array}{l}0.061 \\
{[0.007]} \\
-0.237^{\star \star \star} \\
{[0.061]} \\
\text { Neg. }{ }^{\star \star \star} \\
\text { Neg. } \\
\text { Neg. }{ }^{*} \\
\text { Pos. }^{* \star} \\
0 \\
\text { Neg. }^{* \star \star} \\
\text { Neg. }^{* \star \star} \\
\text { Neg. }^{*} \\
\text { Pos. } \\
\text { Pos. }^{*} \\
\text { Neg. }\end{array}$ & $\begin{array}{l}0.023 \\
{[0.007]} \\
-0.219^{* * *} \\
{[0.061]} \\
\text { Neg. }{ }^{* \star *} \\
\text { Neg. } \\
\text { Neg. } \\
\text { Pos. }^{* \star} \\
0 \\
\text { Neg. }^{* * *} \\
\text { Neg. }^{* \star \star} \\
\text { Neg. }{ }^{*} \\
\text { Pos. }^{*} \\
\text { Pos. } \\
\text { Neg. } \\
0 \\
\text { Pos. } \\
\text { Pos. } \\
\text { Neg. } \\
\text { Neg. } \\
0\end{array}$ & $\begin{array}{l}-0.005 \\
{[0.007]} \\
-0.203^{* * *} \\
{[0.061]} \\
\text { Neg. }{ }^{* * *} \\
\text { Neg. } \\
\text { Neg. } \\
\text { Pos. }{ }^{* * *} \\
0 \\
\text { Neg. }{ }^{* * *} \\
\text { Neg. }{ }^{* * *} \\
\text { Neg. } \\
\text { Pos. } \\
\text { Pos. }{ }^{* *} \\
\text { Neg. } \\
0 \\
\text { Pos. } \\
\text { Pos. } \\
\text { Neg. } \\
\text { Neg. }{ }^{* * *} \\
0 \\
\text { Neg. }{ }^{* * *} \\
\text { Neg. }{ }^{* * *} \\
\text { Neg. }{ }^{*}\end{array}$ & $\begin{array}{l}-0.008 \\
{[0.008]} \\
-0.218^{\star * *} \\
{[0.061]} \\
\text { Neg. }{ }^{* * *} \\
\text { Neg. } \\
\text { Neg. } \\
\text { Pos. } \\
0 \\
\text { Neg. }{ }^{* *} \\
\text { Neg. }{ }^{* * *} \\
\text { Neg. } \\
\text { Pos. } \\
\text { Pos. } \\
\text { Neg. } \\
0 \\
\text { Pos. } \\
\text { Pos. } \\
\text { Neg. } \\
\text { Neg. }{ }^{* *} \\
0 \\
\text { Neg. }{ }^{* * *} \\
\text { Neg. }{ }^{* * *} \\
\text { Neg. }{ }^{*} \\
\text { Pos. }{ }^{* * *}\end{array}$ & 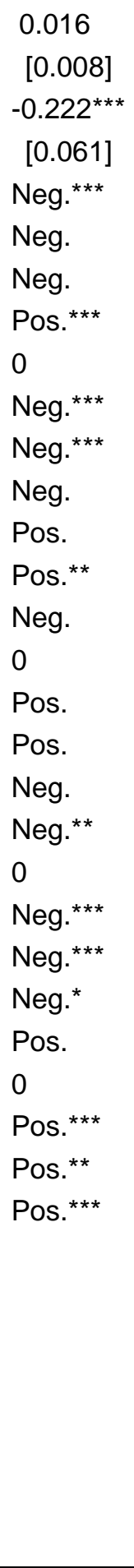 & $\begin{array}{l}\text { 0.016 } \\
{[0.008]} \\
-0.243^{\star * *} \\
{[0.061]} \\
\text { Neg. }{ }^{* *} \\
\text { Neg. } \\
\text { Neg. } \\
\text { Pos. }{ }^{* * *} \\
0 \\
\text { Neg. }{ }^{* * *} \\
\text { Neg. }{ }^{* *} \\
\text { Neg. } \\
\text { Pos. } \\
\text { Pos. }{ }^{* *} \\
\text { Neg. } \\
0 \\
\text { Pos. } \\
\text { Pos. } \\
\text { Neg. } \\
\text { Neg. }{ }^{* *} \\
0 \\
\text { Neg. }{ }^{* *} \\
\text { Neg. } \\
\text { Neg. } \\
\text { Pos. } \\
0 \\
\text { Pos. }{ }^{* * *} \\
\text { Pos. }{ }^{*} \\
\text { Pos. }{ }^{* *} \\
0 \\
\text { Neg. }{ }^{* *} \\
\text { Neg. }{ }^{* *} \\
\text { Neg. }{ }^{* * *} \\
\text { Neg. }{ }^{* * *} \\
\text { Neg. }{ }^{* *} \\
\text { Neg. }{ }^{* * *} \\
\text { Neg. }{ }^{* *}\end{array}$ \\
\hline $\begin{array}{l}\text { Observations } \\
\text { Adjusted } \mathrm{R}^{2}\end{array}$ & $\begin{array}{l}2,672 \\
0.0098\end{array}$ & $\begin{array}{l}2,672 \\
0.0245\end{array}$ & $\begin{array}{l}2,672 \\
0.0292\end{array}$ & $\begin{array}{l}2,672 \\
0.0366\end{array}$ & $\begin{array}{l}2,672 \\
0.0441\end{array}$ & $\begin{array}{l}2,672 \\
0.0471 \\
\end{array}$ & \begin{tabular}{|l|}
2,672 \\
0.0672 \\
\end{tabular} \\
\hline
\end{tabular}

Reform is equal to 1 if the individual belongs to the Treatment group and equal to 0 if he/she belongs to the Comparison group. Values for the reference groups are marked as 0 .Level of statistical significance is indicated by ${ }^{* * *} p<0.01,{ }^{* *} p<0.05,{ }^{*} p<0.1$ 


\section{Appendix Table A.}

Estimates of the effect of the Establishment Reform on the probability of employment in 2012 as compared to the effect for the Comparison group in 2011. Both sexes. Standard errors in brackets.

\begin{tabular}{|c|c|c|c|c|c|c|c|c|}
\hline Variables & (1) & (2) & (3) & (4) & (5) & (6) & (7) & (8) \\
\hline Reform & $\begin{array}{l}0.017^{* *} \\
{[0.008}\end{array}$ & $\begin{array}{c}-0.007 \\
{[0.008]}\end{array}$ & $\begin{array}{c}-0.029^{* * *} \\
{[0.008]}\end{array}$ & $\begin{array}{c}-0.032^{* * *} \\
{[0.0081}\end{array}$ & $\begin{array}{c}-0.034^{* * *} \\
{[0.008]}\end{array}$ & $\begin{array}{c}-0.030^{\star * *} \\
{[0.008]}\end{array}$ & $\begin{array}{c}-0.027^{* * *} \\
{[0.008]}\end{array}$ & $\begin{array}{c}0,018 \\
{[0.011]}\end{array}$ \\
\hline Female & $\begin{array}{c}-0.167^{* * *} \\
{[0.007]}\end{array}$ & $\begin{array}{c}-0.167^{\star * *} \\
{[0.007]}\end{array}$ & $\begin{array}{c}-0.145^{\star * *} \\
{[0.008]}\end{array}$ & $\begin{array}{c}-0.139^{* * *} \\
{[0.008]}\end{array}$ & $\begin{array}{c}-0.142^{* * *} \\
{[0.008]}\end{array}$ & $\begin{array}{c}-0.143^{* * *} \\
{[0.008]}\end{array}$ & $\begin{array}{c}-0.146^{* * *} \\
{[0.007]}\end{array}$ & $\begin{array}{c}-0.146^{* * *} \\
{[0.007]}\end{array}$ \\
\hline Year of birth & $\begin{array}{c}0.005^{* * *} \\
{[0.000]}\end{array}$ & $\begin{array}{c}0.005^{* * *} \\
{[0.000]}\end{array}$ & $\begin{array}{c}0.005^{* * *} \\
{[0.000]}\end{array}$ & $\begin{array}{c}0.005^{\star * *} \\
{[0.000]}\end{array}$ & $\begin{array}{c}0.005^{\star * *} \\
{[0.000]}\end{array}$ & $\begin{array}{c}0.005^{\star * *} \\
{[0.000]}\end{array}$ & $\begin{array}{c}0.005^{\star * *} \\
{[0.000]}\end{array}$ & $\begin{array}{c}0.005^{\star * *} \\
{[0.000]}\end{array}$ \\
\hline Afghanistan & & $\begin{array}{c}0.052^{* * *} \\
{[0.017]}\end{array}$ & $\begin{array}{c}0.079^{* * *} \\
{[0.018]}\end{array}$ & $\begin{array}{c}0.093^{* * *} \\
{[0.018]}\end{array}$ & $\begin{array}{c}0.097^{\star * *} \\
{[0.018]}\end{array}$ & $\begin{array}{c}0.097^{* * *} \\
{[0.018]}\end{array}$ & $\begin{array}{c}0.098^{\star \star *} \\
{[0.018]}\end{array}$ & $\begin{array}{c}0.096^{\star * *} \\
{[0.018]}\end{array}$ \\
\hline Eritrea & & $\begin{array}{c}0.106^{* \star *} \\
{[0.015]}\end{array}$ & $\begin{array}{c}0.106^{* * *} \\
{[0.015]}\end{array}$ & $\begin{array}{c}0.111^{\star * *} \\
{[0.015]}\end{array}$ & $\begin{array}{c}0.107^{\star \star *} \\
{[0.015]}\end{array}$ & $\begin{array}{c}0.111^{\star \star *} \\
{[0.015]}\end{array}$ & $\begin{array}{c}0.092^{* * *} \\
{[0.016]}\end{array}$ & $\begin{array}{c}0.100^{\star * *} \\
{[0.016]}\end{array}$ \\
\hline Europa & & $0.089^{* * *}$ & $0.080^{* * *}$ & $0.082^{* * *}$ & $0.080^{\star * *}$ & $0.081^{* * *}$ & $0.101^{* * *}$ & $0.103^{* * *}$ \\
\hline Iraq & & $\begin{array}{c}{[0.025]} \\
0\end{array}$ & $\begin{array}{c}{[0.024]} \\
0\end{array}$ & $\begin{array}{c}{[0.025]} \\
0\end{array}$ & $\begin{array}{c}{[0.024]} \\
0\end{array}$ & $\begin{array}{c}{[0.024]} \\
0\end{array}$ & $\begin{array}{c}{[0.024]} \\
0\end{array}$ & $\begin{array}{c}{[0.024]} \\
0\end{array}$ \\
\hline Iran & & $\begin{array}{c}0.111^{* * *} \\
{[0.018]}\end{array}$ & $\begin{array}{c}0.088^{* * *} \\
{[0.018]}\end{array}$ & $\begin{array}{c}0.080^{* * *} \\
{[0.018]}\end{array}$ & $\begin{array}{c}0.087^{* * *} \\
{[0.018]}\end{array}$ & $\begin{array}{c}0.088^{* * *} \\
{[0.018]}\end{array}$ & $\begin{array}{c}0.088^{* * *} \\
{[0.018]}\end{array}$ & $\begin{array}{c}0.083^{* * *} \\
{[0.018]}\end{array}$ \\
\hline Somalia & & $\begin{array}{c}-0.025^{\star *} \\
{[0.011]}\end{array}$ & $\begin{array}{c}0.012 \\
{[0.011]}\end{array}$ & $\begin{array}{c}0.004 \\
{[0.012]}\end{array}$ & $\begin{array}{c}0.001 \\
{[0.012]}\end{array}$ & $\begin{array}{c}0.00 \\
{[0.012]}\end{array}$ & $\begin{array}{c}0.02 \\
{[0.012]}\end{array}$ & $\begin{array}{l}0.027^{\star *} \\
{[0.012]}\end{array}$ \\
\hline Other African & & $\begin{array}{c}0.101^{* * *} \\
{[0.017]}\end{array}$ & $\begin{array}{c}0.101^{* * *} \\
{[0.017]}\end{array}$ & $\begin{array}{c}0.102^{* * *} \\
{[0.017]}\end{array}$ & $\begin{array}{c}0.105^{\star * *} \\
{[0.017]}\end{array}$ & $\begin{array}{c}0.108^{* * *} \\
{[0.017]}\end{array}$ & $\begin{array}{c}0.097^{* * *} \\
{[0.017]}\end{array}$ & $\begin{array}{c}0.105^{\star * *} \\
{[0.017]}\end{array}$ \\
\hline Other Asia & & $\begin{array}{c}0.153^{* * *} \\
{[0.020]}\end{array}$ & $\begin{array}{c}0.139^{* * *} \\
{[0.020]}\end{array}$ & $\begin{array}{c}0.134^{* * *} \\
{[0.020]}\end{array}$ & $\begin{array}{c}0.136^{* * *} \\
{[0.020]}\end{array}$ & $\begin{array}{c}0.137^{* * *} \\
{[0.020]}\end{array}$ & $\begin{array}{c}0.124^{* * *} \\
{[0.020]}\end{array}$ & $\begin{array}{c}0.122^{* * *} \\
{[0.020]}\end{array}$ \\
\hline Oth. Middle East & & $\begin{array}{l}0.041^{* *} \\
{[0.019]}\end{array}$ & $\begin{array}{l}0.038^{* *} \\
{[0.019]}\end{array}$ & $\begin{array}{l}0.040^{* *} \\
{[0.019]}\end{array}$ & $\begin{array}{l}0.046^{* *} \\
{[0.019]}\end{array}$ & $\begin{array}{l}0.047^{* *} \\
{[0.019]}\end{array}$ & $\begin{array}{c}0.066^{* * *} \\
{[0.019]}\end{array}$ & $\begin{array}{c}0.065^{\star * *} \\
{[0.019]}\end{array}$ \\
\hline Other Regions & & $0.155^{\star * \star}$ & $0.158^{* * *}$ & $0.151^{* * *}$ & $0.156^{\star * *}$ & $0.152^{* * *}$ & $0.144^{* * *}$ & $0.142^{* * *}$ \\
\hline Primary $<9$ yrs & & {$[0.048]$} & $\begin{array}{c}{[0.048]} \\
0\end{array}$ & $\begin{array}{c}{[0.048]} \\
0\end{array}$ & $\begin{array}{c}{[0.047]} \\
0\end{array}$ & $\begin{array}{c}{[0.047]} \\
0\end{array}$ & $\begin{array}{c}{[0.047]} \\
0\end{array}$ & $\begin{array}{c}{[0.047]} \\
0\end{array}$ \\
\hline Lower Secondary & & & $\begin{array}{l}0.034^{* *} \\
{[0.015]}\end{array}$ & $\begin{array}{l}0.032^{* *} \\
{[0.015]}\end{array}$ & $\begin{array}{l}0.030^{* *} \\
{[0.015]}\end{array}$ & $\begin{array}{l}0.030^{* *} \\
{[0.015]}\end{array}$ & $\begin{array}{c}0.026^{*} \\
{[0.015]}\end{array}$ & $\begin{array}{c}0.024^{*} \\
{[0.014]}\end{array}$ \\
\hline Upper Secondary & & & $\begin{array}{l}0.091^{* * *} \\
{[0.011]}\end{array}$ & $\begin{array}{l}0.091^{* * *} \\
{[0.011]}\end{array}$ & $\begin{array}{c}0.089^{* * *} \\
{[0.011]}\end{array}$ & $\begin{array}{c}0.089^{* * *} \\
{[0.011]}\end{array}$ & $\begin{array}{c}0.085^{\star * *} \\
{[0.011]}\end{array}$ & $\begin{array}{c}0.084^{* * *} \\
{[0.011]}\end{array}$ \\
\hline Post Secondary & & & $\begin{array}{c}0.075^{\star * *} \\
{[0.011]}\end{array}$ & $\begin{array}{c}0.077^{* * *} \\
{[0.011]}\end{array}$ & $\begin{array}{c}0.076^{\star * *} \\
{[0.011]}\end{array}$ & $\begin{array}{c}0.076^{* * *} \\
{[0.011]}\end{array}$ & $\begin{array}{c}0.072^{* * *} \\
{[0.011]}\end{array}$ & $\begin{array}{c}0.070^{* * *} \\
{[0.011]}\end{array}$ \\
\hline $\begin{array}{l}\text { Unknown Educ. } \\
\text { Own Housing }\end{array}$ & & & $\begin{array}{c}-0.078^{* * *} \\
{[0.011]}\end{array}$ & $\begin{array}{c}-0.078^{* * *} \\
{[0.010]} \\
0\end{array}$ & $\begin{array}{c}-0.065^{\star \star *} \\
{[0.011]} \\
0\end{array}$ & $\begin{array}{c}-0.063^{\star * *} \\
{[0.011]} \\
0\end{array}$ & $\begin{array}{c}-0.062^{\star \star *} \\
{[0.010]} \\
0\end{array}$ & $\begin{array}{c}-0.064^{\star * *} \\
{[0.010]} \\
0\end{array}$ \\
\hline Quota Refugee & & & & $\begin{array}{c}-0.02 \\
{[0.012]}\end{array}$ & $\begin{array}{l}-0.015 \\
{[0.012]}\end{array}$ & $\begin{array}{l}-0.023^{*} \\
{[0.012]}\end{array}$ & $\begin{array}{c}-0.040^{* * *} \\
{[0.013]}\end{array}$ & $\begin{array}{l}0.045^{\star *} \\
{[0.018]}\end{array}$ \\
\hline Mig. Board Hous & & & & $\begin{array}{c}-0.052^{* * *} \\
{[0.009]}\end{array}$ & $\begin{array}{c}-0.062^{* * *} \\
{[0.009]}\end{array}$ & $\begin{array}{c}-0.053^{* * *} \\
{[0.009]}\end{array}$ & $\begin{array}{c}-0.036^{\star * *} \\
{[0.009]}\end{array}$ & $\begin{array}{c}-0.016 \\
{[0.011]}\end{array}$ \\
\hline Family Reunion & & & & $\begin{array}{c}-0.097^{* * *} \\
{[0.013]}\end{array}$ & $\begin{array}{c}-0.096^{\star * *} \\
{[0.013]}\end{array}$ & $\begin{array}{c}-0.102^{\star * \star} \\
{[0.014]}\end{array}$ & $\begin{array}{c}-0.091^{* * *} \\
{[0.013]}\end{array}$ & $\begin{array}{c}-0.064^{* * *} \\
{[0.017]}\end{array}$ \\
\hline
\end{tabular}


Appendix Table A cont.

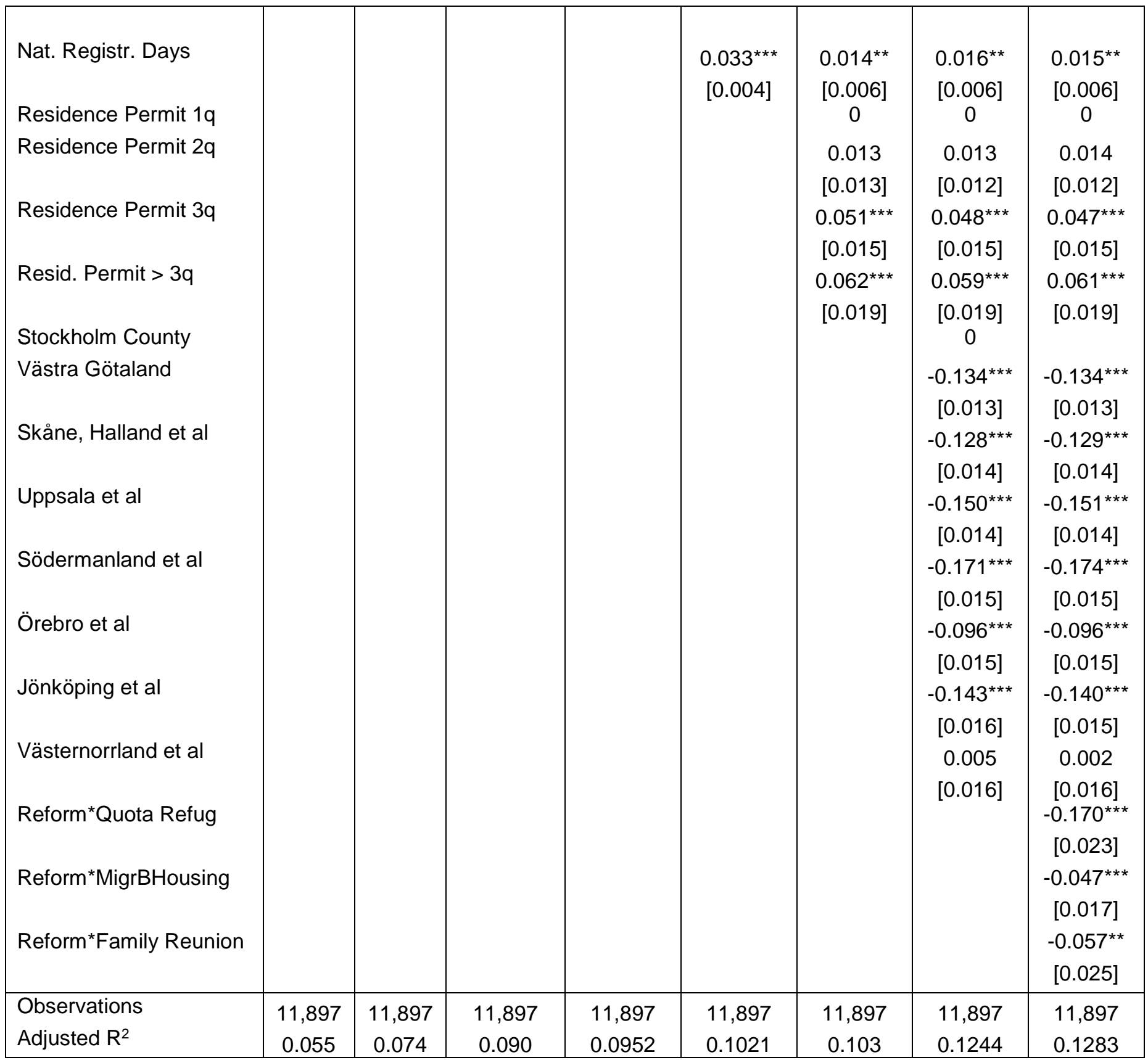

Reform is equal to 1 if the individual belongs to the Treatment group and equal to 0 if he/she belongs to the Comparison group. Values for the reference groups are denoted by 0. Level of statistical significance is indicated by

${ }^{* * *} p<0.01,{ }^{* *} p<0.05,{ }^{*} p<0.1$. 


\section{Appendix Table B.}

Estimates of the effect of the Establishment Reform on log annual earnings in 2012 as compared to the effect for the Comparison group in 2011. Both sexes.

\begin{tabular}{|c|c|c|c|c|c|c|c|}
\hline Variables & (1) & (2) & (3) & (4) & (5) & (6) & (7) \\
\hline Reform & $\begin{array}{c}0.090 \\
{[0.056]}\end{array}$ & $\begin{array}{c}0.061 \\
{[0.058]}\end{array}$ & $\begin{array}{c}0.023 \\
{[0.059]}\end{array}$ & $\begin{array}{l}-0.005 \\
{[0.059]}\end{array}$ & $\begin{array}{l}-0.008 \\
{[0.059]}\end{array}$ & $\begin{array}{c}0.016 \\
{[0.060]}\end{array}$ & $\begin{array}{c}0.016 \\
{[0.059]}\end{array}$ \\
\hline Female & $\begin{array}{c}-0.239^{\star \star *} \\
{[0.061]}\end{array}$ & $\begin{array}{c}-0.237^{\star * *} \\
{[0.061]}\end{array}$ & $\begin{array}{c}-0.219^{* * *} \\
{[0.061]}\end{array}$ & $\begin{array}{c}-0.203^{\star \star *} \\
{[0.061]}\end{array}$ & $\begin{array}{c}-0.218^{* * *} \\
{[0.061]}\end{array}$ & $\begin{array}{c}-0.222^{* * *} \\
{[0.061]}\end{array}$ & $\begin{array}{c}-0.243^{\star \star \star} \\
{[0.061]}\end{array}$ \\
\hline Year of birth & $\begin{array}{c}-0.012^{* * *} \\
{[0.003]}\end{array}$ & $\begin{array}{c}-0.010^{* * *} \\
{[0.003]}\end{array}$ & $\begin{array}{c}-0.011^{* * *} \\
{[0.003]}\end{array}$ & $\begin{array}{c}-0.011^{* * *} \\
{[0.003]}\end{array}$ & $\begin{array}{c}-0.011^{* * *} \\
{[0.003]}\end{array}$ & $\begin{array}{c}-0.011^{\star * *} \\
{[0.003]}\end{array}$ & $\begin{array}{c}-0.010^{* * *} \\
{[0.003]}\end{array}$ \\
\hline Afghanistan & & $\begin{array}{c}-0.185 \\
{[0.136]}\end{array}$ & $\begin{array}{l}-0.175 \\
{[0.137]}\end{array}$ & $\begin{array}{l}-0.093 \\
{[0.138]}\end{array}$ & $\begin{array}{l}-0.051 \\
{[0.137]}\end{array}$ & $\begin{array}{l}-0.042 \\
{[0.137]}\end{array}$ & $\begin{array}{l}-0.037 \\
{[0.136]}\end{array}$ \\
\hline Eritrea & & $\begin{array}{l}-0.206^{*} \\
{[0.110]}\end{array}$ & $\begin{array}{c}-0.243^{\star \star} \\
{[0.111]}\end{array}$ & $\begin{array}{l}-0.134 \\
{[0.114]}\end{array}$ & $\begin{array}{l}-0.126 \\
{[0.114]}\end{array}$ & $\begin{array}{l}-0.099 \\
{[0.114]}\end{array}$ & $\begin{array}{l}-0.165 \\
{[0.115]}\end{array}$ \\
\hline Europa & & $0.440^{\star *}$ & $0.426^{\star *}$ & $0.474^{* * *}$ & $0.485^{* * *}$ & $0.480^{\star * *}$ & $0.528^{* * *}$ \\
\hline Iraq & & $\begin{array}{c}{[0.174]} \\
0\end{array}$ & $\begin{array}{c}{[0.174]} \\
0\end{array}$ & $\begin{array}{c}{[0.175]} \\
0\end{array}$ & $\begin{array}{c}{[0.175]} \\
0\end{array}$ & $\begin{array}{c}{[0.174]} \\
0\end{array}$ & $\begin{array}{c}{[0.174]} \\
0\end{array}$ \\
\hline Iran & & $\begin{array}{c}-0.395^{\star \star *} \\
{[0.128]}\end{array}$ & $\begin{array}{c}-0.405^{\star \star \star} \\
{[0.128]}\end{array}$ & $\begin{array}{c}-0.383^{* * *} \\
{[0.129]}\end{array}$ & $\begin{array}{c}-0.331^{* *} \\
{[0.128]}\end{array}$ & $\begin{array}{c}-0.331^{* * *} \\
{[0.128]}\end{array}$ & $\begin{array}{c}-0.373^{* * *} \\
{[0.128]}\end{array}$ \\
\hline Somalia & & $\begin{array}{c}-0.295^{\star * *} \\
{[0.093]}\end{array}$ & $\begin{array}{c}-0.289^{\star * *} \\
{[0.095]}\end{array}$ & $\begin{array}{c}-0.263^{\star \star *} \\
{[0.097]}\end{array}$ & $\begin{array}{c}-0.256^{\star * *} \\
{[0.096]}\end{array}$ & $\begin{array}{c}-0.261^{* * *} \\
{[0.096]}\end{array}$ & $\begin{array}{c}-0.235^{* *} \\
{[0.098]}\end{array}$ \\
\hline Other African & & $\begin{array}{l}-0.207^{*} \\
{[0.121]}\end{array}$ & $\begin{array}{l}-0.206^{*} \\
{[0.121]}\end{array}$ & $\begin{array}{c}-0.094 \\
{[0.124]}\end{array}$ & $\begin{array}{l}-0.069 \\
{[0.123]}\end{array}$ & $\begin{array}{l}-0.065 \\
{[0.123]}\end{array}$ & $\begin{array}{c}-0.099 \\
{[0.123]}\end{array}$ \\
\hline Other Asia & & $\begin{array}{c}0.045 \\
{[0.134]}\end{array}$ & $\begin{array}{c}0.04 \\
{[0.134]}\end{array}$ & $\begin{array}{c}0.067 \\
{[0.134]}\end{array}$ & $\begin{array}{c}0.082 \\
{[0.134]}\end{array}$ & $\begin{array}{c}0.096 \\
{[0.134]}\end{array}$ & $\begin{array}{c}0.043 \\
{[0.133]}\end{array}$ \\
\hline Oth. Middle East & & $\begin{array}{c}0.266^{*} \\
{[0.145]}\end{array}$ & $\begin{array}{c}0.260^{*} \\
{[0.144]}\end{array}$ & $\begin{array}{l}0.291^{\star *} \\
{[0.144]}\end{array}$ & $\begin{array}{l}0.327^{\star *} \\
{[0.144]}\end{array}$ & $\begin{array}{l}0.328^{\star *} \\
{[0.144]}\end{array}$ & $\begin{array}{l}0.347^{\star *} \\
{[0.143]}\end{array}$ \\
\hline $\begin{array}{l}\text { Other Regions } \\
\text { Primary }<9 \text { yrs }\end{array}$ & & $\begin{array}{c}-0.113 \\
{[0.298]}\end{array}$ & $\begin{array}{c}-0.129 \\
{[0.298]} \\
0\end{array}$ & $\begin{array}{c}-0.087 \\
{[0.297]} \\
0\end{array}$ & $\begin{array}{c}-0.058 \\
{[0.296]} \\
0\end{array}$ & $\begin{array}{c}-0.041 \\
{[0.295]} \\
0\end{array}$ & $\begin{array}{c}-0.133 \\
{[0.293]} \\
0\end{array}$ \\
\hline Lower Secondary & & & $\begin{array}{c}0.113 \\
{[0.106]}\end{array}$ & $\begin{array}{c}0.103 \\
{[0.105]}\end{array}$ & $\begin{array}{c}0.101 \\
{[0.105]}\end{array}$ & $\begin{array}{c}0.104 \\
{[0.105]}\end{array}$ & $\begin{array}{c}0.086 \\
{[0.104]}\end{array}$ \\
\hline Upper Secondary & & & $\begin{array}{c}0.067 \\
{[0.078]}\end{array}$ & $\begin{array}{c}0.059 \\
{[0.078]}\end{array}$ & $\begin{array}{c}0.061 \\
{[0.078]}\end{array}$ & $\begin{array}{c}0.067 \\
{[0.078]}\end{array}$ & $\begin{array}{c}0.068 \\
{[0.077]}\end{array}$ \\
\hline Post Secondary & & & $\begin{array}{l}-0.109 \\
{[0.080]}\end{array}$ & $\begin{array}{c}-0.107 \\
{[0.080]}\end{array}$ & $\begin{array}{l}-0.098 \\
{[0.080]}\end{array}$ & $\begin{array}{l}-0.096 \\
{[0.080]}\end{array}$ & $\begin{array}{c}-0.091 \\
{[0.079]}\end{array}$ \\
\hline $\begin{array}{l}\text { Unknown Educ. } \\
\text { Own Housing }\end{array}$ & & & $\begin{array}{c}-0.313^{\star \star *} \\
{[0.104]}\end{array}$ & $\begin{array}{c}-0.307^{\star * *} \\
{[0.103]} \\
0\end{array}$ & $\begin{array}{c}-0.252^{\star *} \\
{[0.104]} \\
0\end{array}$ & $\begin{array}{c}-0.233^{* *} \\
{[0.104]} \\
0\end{array}$ & $\begin{array}{c}-0.204^{* *} \\
{[0.103]} \\
0\end{array}$ \\
\hline Quota Refugee & & & & $\begin{array}{c}-0.307^{* * *} \\
{[0.086]}\end{array}$ & $\begin{array}{c}-0.294^{* * *} \\
{[0.086]}\end{array}$ & $\begin{array}{c}-0.309^{\star * *} \\
{[0.087]}\end{array}$ & $\begin{array}{c}-0.210^{* *} \\
{[0.105]}\end{array}$ \\
\hline Mig. Board Housing & & & & $\begin{array}{c}-0.272^{\star * *} \\
{[0.065]}\end{array}$ & $\begin{array}{c}-0.321^{* * *} \\
{[0.066]}\end{array}$ & $\begin{array}{c}-0.257^{\star * *} \\
{[0.070]}\end{array}$ & $\begin{array}{l}-0.118 \\
{[0.074]}\end{array}$ \\
\hline Family Reunion & & & & $\begin{array}{l}-0.232^{*} \\
{[0.135]}\end{array}$ & $\begin{array}{l}-0.233^{*} \\
{[0.135]}\end{array}$ & $\begin{array}{l}-0.262^{*} \\
{[0.135]}\end{array}$ & $\begin{array}{l}-0.148 \\
{[0.136]}\end{array}$ \\
\hline
\end{tabular}


Appendix Table B. cont.

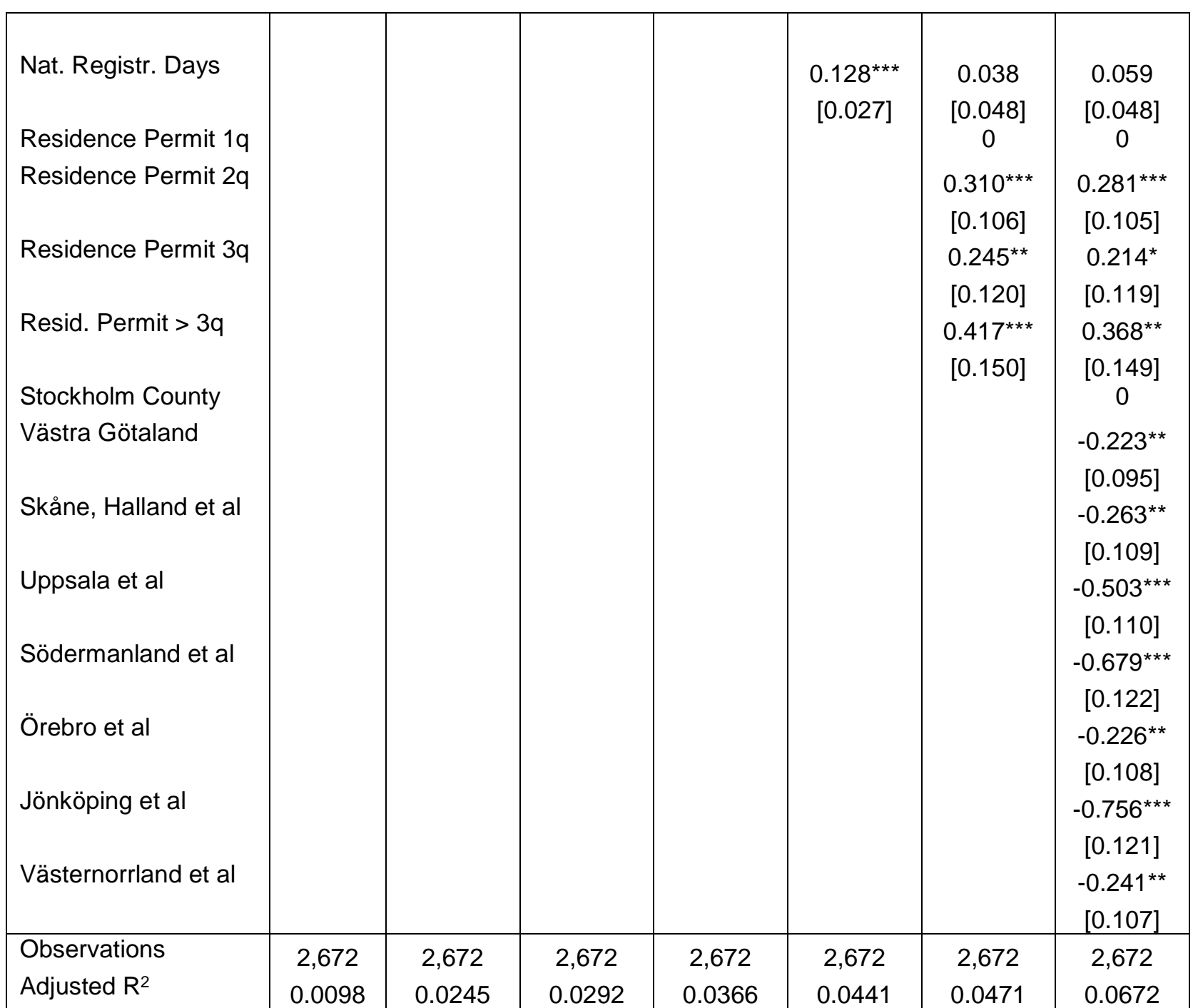

Reform is equal to 1 if the individual belongs to the Treatment group and equal to 0 if he/she belongs to the Comparison group. Values for the reference groups are denoted by 0 .Level of statistical significance is indicated by ${ }^{* * *} p<0.01,{ }^{* *} p<0.05,{ }^{*} p<0.1$. 